\title{
The Scientific Institutionalization of Indigenous Knowledge in Mexico: A Historical Analysis of the Medical and Surgical Academy of Puebla de los Ángeles
}

\author{
Susana Carolina Guzmán-Rosas \\ Centro de Investigación y de Estudios Avanzados del Instituto Politécnico Nacional, Mexico City, Mexico \\ Email: sguzmanr@cinvestav.mx
}

Received 5 June 2015; accepted 21 July 2015; published 24 July 2015

Copyright (C) 2015 by author and Scientific Research Publishing Inc.

This work is licensed under the Creative Commons Attribution International License (CC BY).

http://creativecommons.org/licenses/by/4.0/

(c) (i) Open Access

\begin{abstract}
This paper presents a historical analysis on the Medical and Surgical Academy of Puebla de los Ángeles, which was founded in Mexico in 1824. The methodology of the science history was used, particularly the historiography. The above mentioned Academy can be considered the first institution that in the Independent period of Mexico approached scientifically the indigenous knowledge on medicinal plants, across the disciplines as the botany, the chemistry and the medicine. In this academy the first two Mexican scientific works in the analyzed topic were published; the first one was a book on botany and the second one was a proposal for a Mexican pharmacopoeia. Furthermore there was a particular way of hierarchy relation between the characters of the indigenous knowledge and the characters of the scientific knowledge, which would become stronger in the approaches of the epochs and future institutions later to the academy's life. Nevertheless, this institution was buried in the science history, due to her rivalries with another scientific institution that obtained greater diffusion in the topic and denied the credit to the contributions and the existence of the Academy of Puebla de los Ángeles.
\end{abstract}

\section{Keywords}

Scientific Institutionalization, Indigenous Knowledge, Botanical Charts, Mexican Pharmacopoeia, Academia Médico Quirúrgica de Puebla de los Ángeles 


\section{Introduction}

From a historiographical study, this paper presents the findings of an analysis on La Academia Médico Quirúrgica de Puebla de los Ángeles (the Medical and Surgical Academy of Puebla de los Ángeles), realized during the year 2014 with the purpose to show the place that the history of science has given to this institution for his contributions to the botany, chemistry and medicine. In this way, the history develops highlighting subjects as the foundation process, the social sectors involved, the main organization, the researches involved and his particular interest in the indigenous knowledge on medical plants, as well as the scientific works published and the factors that influenced its closing down.

The Medical and Surgical Academy of Puebla de los Ángeles was founded in 1824, although its background dated back to many years ago and it was established in a time when an illustrated vision of the sciences in the city of Puebla flourished, place where a notable interest was registered by the field of the botany, particularly in what concerns the use of the national indigenous knowledge on medicinal plants and his scientific argument. This can be estimated in the century XVIII, when two main characters would appear on scene and take over centers that would have a particular importance for the topic in development.

The first character was the botanist and chemist José Ignacio Rodríguez Alconedo who in 1791 would be the person in charge of la Farmacia de San Nicolás Tolentino de Puebla (the San Nicolas Tolentino Pharmacy of Puebla). In this position he began the refurbishing and redecoration of the pharmacy and decided to decorate all the doors of all the shelves with oil paintings on each one of them, so they could show the importance of the botany and its relation with art and other sciences as well as emphasize the magnitude and orientation that he wanted for the pharmacy's works. Ramírez Alconedo asked Miguel de Zendejas to execute the work piece (Figure 1) named El Almacén (The Warehouse), but he was the intellectual author of each one of the details for the paintings done for the San Nicolas Tolentino Pharmacy of Puebla. These paintings would show the enormous influence of the intellectual and philosophic streams from the French Illustration [1].

On a fragment of above mentioned pictures you can appreciate a strong relation between botany and chemistry as well as with the knowledge appliance of both disciplines. These three concepts are represented with female bodies. The female representation of chemistry carries a flask while the botanical female representation carries a prickly pear (Nopal) representing in the concept of autochthone allegorically [1]. Besides the female representations of chemistry and botanic, it comes the female representation of the appliance, which appears touching the shoulder of botanic and carrying a goose feather in the right hand and a branch of olive tree in the left side representing the written works and the recognizance for the dedication and appliance in the scientific activities.

The second character involved was Antonio de La Cal y Bracho (a botanist from Burgos) who had arrived to the city of Puebla in 1795 getting the title of main botanist at the Hospital Real de San Pedro (Royal Hospital of San Pedro) a year later, and having the title of spokesman at the Botanical Garden in Madrid, depending of Casimiro Gómez Ortega and Miguel Barnades Clarís [2]. In future years De la Cal would reappear leading the first effort and the works to make a Mexican pharmacopeia.
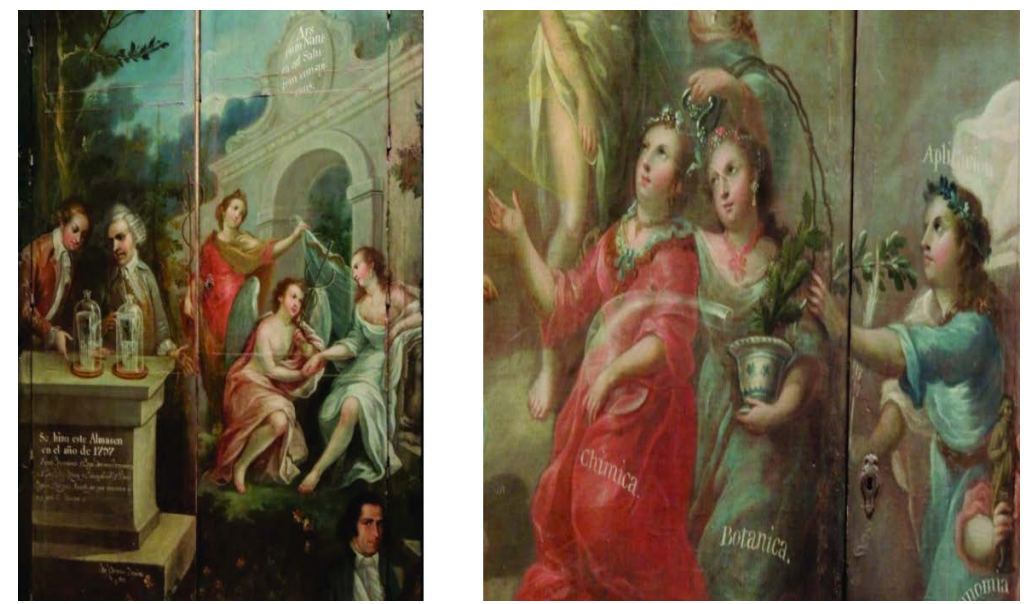

Figure 1. "El almacén” (the warehouse), oil paintings (fragments). Photographs: own file. Author: Miguel Jerónimo de Zendejas (1797); taken in National Museum of History, Mexico City, México, May 2014. 
Both characters, Rodríguez Alconedo and De la Cal, established a strong relationship. De la Cal might be the person who appears talking to Rodríguez Alconedo on the first fragment on the painting [1]. Besides their friendship, they shared the desire of promoting their knowledge development and placed it into the light of the Illustration. They also shared the aspiration of creating and founding a botanical garden in Puebla; moreover they wanted to achieve the independence of the Real Tribunal del Protomedicato Novohispano (the Royal Tribunal of the Novo Hispanic Medical School) because they, together with the rest of the botanists, were opposed to: 1) the regular inspection for which they would be asked money, and 2) recognize and give the professional title to the members of the association [2]. The above mentioned prominent figures cleverly achieved the support of local governments, civil society and religious authorities, aspects that later would influence the integration of a regional scientific community and the primary institutionalization of the sanitary sector.

For his part, the Royal Hospital of San Pedro was founded in 1545 under de Fray Julián Garcés instructions who would be the first bishop of La Nueva España (Spanish Colony). This institution would be involved in an instauration of a sanitary board whose objective would be to fight against the epidemic that was sticking the city of Puebla. For this reason, academics, city hall and religious authorities gathered to create the Sanitary Board in 1813 [2]. The new sanitary board was as prime objective to solve the health problems and issues in the region. Along with this, doctors were asked to review and enable the titles for the main medicine branches, pointing Revilla, Castillo, De la Cal and Rodríguez Alconedo to help and assist the inspections to the pharmacies. This first commission terminated activities in November 1813 and was reactivated in 1814.

In this way, in spite of being an ancient longing promoted from beginning of the 19th century, the Botanical Garden of Puebla was finally established in 1820 [3], influencing the educational policy and the formation of professionals in health [2]. In this context, the sanitary board assembled particularly by Mariano Anzures, Antonio De la Cal, doctors, surgeons and pharmaceutics teachers from the Royal Hospital of San Pedro along with other members of the above mentioned Sanitary Board indicated that a botanical garden, a botanical, chemical and pharmaceutical academy should be established. This would be completed in 1824 [2].

\section{The First Mexican Institution for the Study of Indigenous Knowledge}

After Agustin de Iturbide gave the assent and the State Congress approved his respective bylaws, the Medical and Surgical Academy of Puebla de los Ángeles was established in 1824 in the building which now is the current Museo de Arte San Pedro (San Pedro Art Museum) located on 2034 North Street of Puebla de los Ángeles city center. In this way, created and assembled by doctors and pharmacists (Figure 2) who wanted to integrate a scientific society, this academy would do works that would contribute in the improvement of the medicine and similar branches academic programs to form professionals in the health sciences [2] [4].

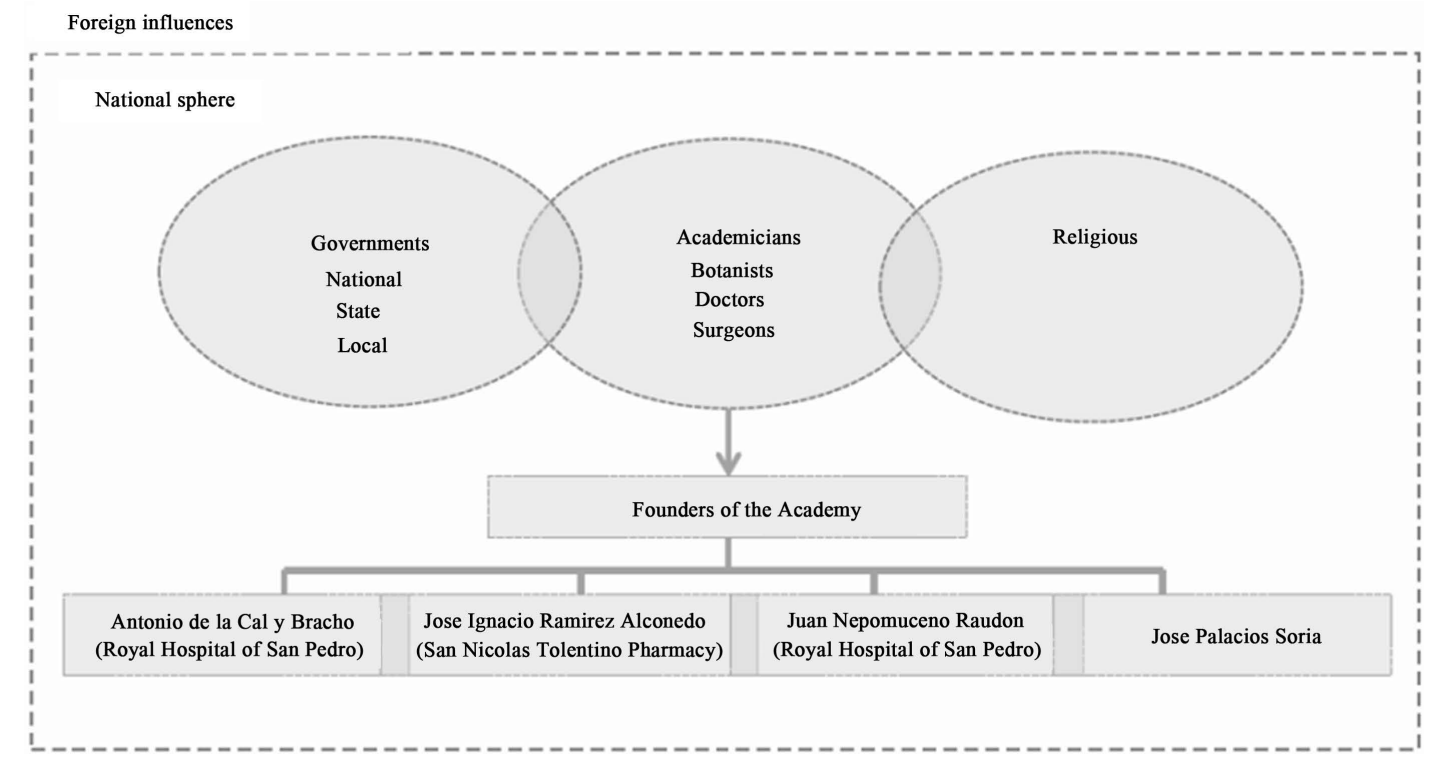

Figure 2. Actors involved in the foundation of the academy. Source: own elaboration, based in [2]-[4]. 
Regarding the academy foundation Juan Nepomuceno Raudón and some other associates declared to have found it as a center destined to show the purposes of the living economy and the biological body possible problems finding the truth in the facts provided and proven by the experience [5]. Other two members of the organizations were José Palacios Soria [3] and Mariano José Cabo Franco who since 1810, would occupy the position as Comisario del Hospital Real de San Pedro (Commissioner at the Royal Hospital of San Pedro) from his position he would supply surgical equipment brought from London, Paris and Barcelona as well as a broad collection of books which would cover the most consolidated and modern theories and authors on medicine.

The functions of the rising academy (Figure 3) were distributed by organizational areas, initially establishing two hierarchy levels between medicine branches which had been in dispute centuries back specially between doctors and surgeons. Doctors would hold key positions while surgeons would hold less important positions for the decision making. Doctors and surgeons heated each other [5].

Regarding the economical aspect, a state tax to maintain and afford the medical teaching institution decreed in 1828 was applied to the academy. The name to this tax was the Pensión del Jardín Botánico (Botanical Garden Pension), and would be a half Real fee on the consumption of each flour loading done in the Capital [2].

To enroll into the academy, the aspirants and honored members who were members of medicine and surgery academic body had to show a high intelligence level, perseverance and skills to keep up with the studies and work in Academy. Once admitted, they would have to enrich it by making donations such as books, instruments sets, or any other equipment [6]. The academy was willing to teach medicine at poor people who would not have the resources to go to the Capital, this course would be divided in four modules (Table 1) which were: Prima (A subject on ill bodies) and Visperas (Subject on healthy bodies), Anatomy and Pharmacy, Chemistry and Botany [2].

Despite the characteristics of the time, the academy could establish and stay in permanent contact with its foreign colleagues, particularly with the academies from The United States of America (New York and Philadelphia) as well as with the scientific centers from France (Montpellier) and Spain. This made to think that it is in the pharmacy and botany where international current flourishing of the regional scientific nationalism is best shown [2]. The foreign influence, mainly the Spanish one, could be noticed due to the fact that the regulations of the Medical and Surgical Academy of Puebla de los Ángeles were built taking after the ones from La Academia Médico Práctica de Barcelona (The Medical Practice Academy of Barcelona) including the organization and the purposes. All members would gather every Thursday to read self-translated works on relevant topics in their different areas, culture or science in general. In these meetings all members would give a presentation on matter whether topic was in their area or not [2].

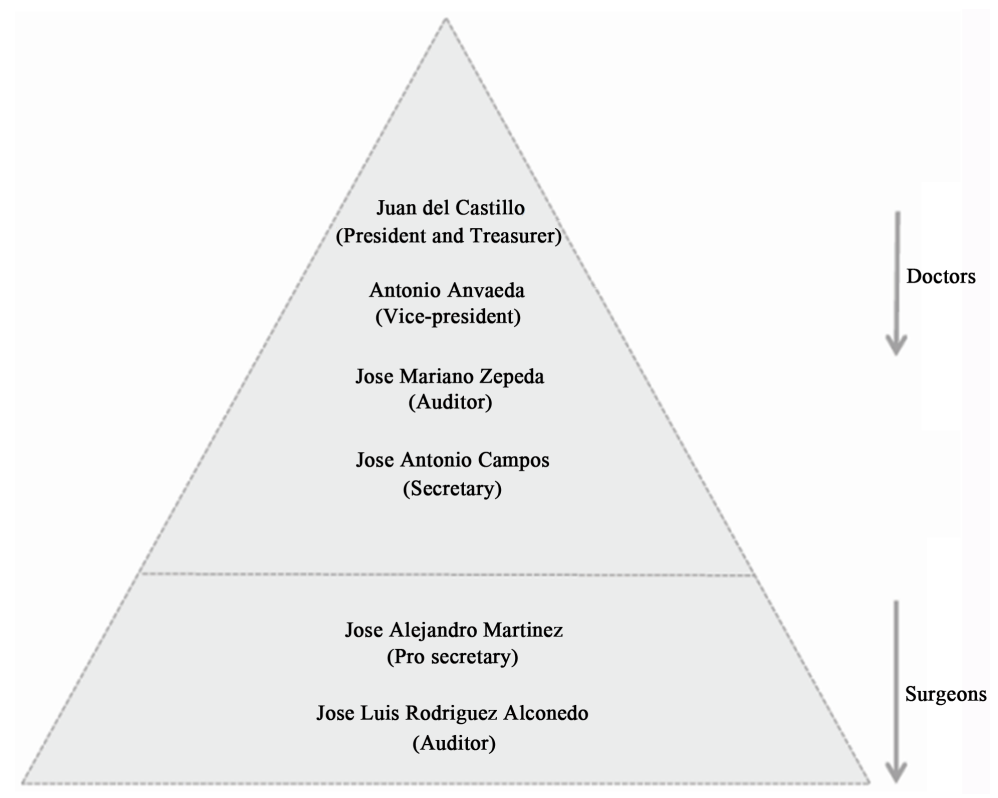

Figure 3. Hierarchy in the initial organization of the academy. Source: own elaboration, based in [2]. 
Table 1. Courses given in the academy.

\begin{tabular}{ccc}
\hline Course & Place of Learning & Titular Teacher \\
Prima & Royal and Pontifical Seminary College & - \\
Vísperas & Royal and Pontifical Seminary College & Botany: Antonio De la Cal \\
Anatomy & San Pedro Hospital & Chemical-Pharmaceutical: Ignacio Echeverría \\
\hline
\end{tabular}

Source: own elaboration, based in [2].

\section{The Academy Works}

The birth of the first Mexican scientific works was noticeable influenced by the circumstances of the actions created by the ending of the independence war in 1821 [7]. This would be an obstacle to introduce foreign works to the country. Previously, particularly at the beginning of the XIX century, it was quite impossible to print books and do other activities due to the rebel movement, high printing costs and the paper shortage [8]. Despite the fact the first press had arrived to Puebla in 1639, it would not be until 1831 when the commissioner of the San Pedro Hospital, Mariano José Cabofranco, would buy a press from Pedro de la Rosa being left as inheritance to the academy [2]. This enabled and allowed Medical and Surgical Academy of Puebla de los Ángeles to begin the promotion and launching works such as: Tablas botánicas (Botanical charts) by Julián Cervantes in 1925 [9], Posología by Cadet in 1929, which was a translation to Spanish of the written work of the Posologie de Cadet by Gassicourt done by Pedro Calderón, and the Ensayo para la Materia Médica Mexicana (Mexican Essay for Medicine) written in 1832 by a commission assembled by Antonio De la Cal y Bracho [10]. From which the first and last are considered to be the first most important scientific Mexican works on botanic and Mexican pharmacopeia.

\subsection{The First Mexican Book on Botanic}

Julián Cervantes, son and disciple of Vicente Cervantes, was a valid teacher in chemistry math, physics, mineralogy and botanic, and he had given this last subject for 6 years in Mexico City. After teaching in Mexico City, he moved to Puebla. His father had gone there in 1775 to perform chemical studies on the Quahuhizquiztli plant, and he ordered the plant distribution to the hospitals in order that it could be used in treatments. Julián Cervantes would travel around Puebla collecting samples to be sent to his father in Mexico City helping him to create a wide state plant catalogue; he helped in the botanical development and to set the medicine basis of that time [11].

In 1825, with support of the Medical and Surgical Academy of Puebla de los Ángeles, Julián de Cervantes published Tablas botánicas (Figure 4) which were presented and promoted into the academy by Antonio De la Cal. The charts were published thinking that they might be of help for the medicine, botanic and pharmacopeia teachers, as well as for those natural history followers.

This book is considered to be the first published book in Mexico on botanic [7] and America [3]. The publishing was broadly promoted and sent to members of the cultural and scientific sector such as Vicente Cervantes, Pablo de la Llave and Lucas Alamán and also it was sent to the ministers of relations, business, tax office, navy, army and central government [2].

In this book Julian de Cervantes, through 13 charts, explained and defined the botanical characteristics of the plants according to their parts. At the end, he included a chart with the names of the types and orders that Casimiro Ortega had established for the botanical basic course which was used to teach at the Real Jardín Botánico de Madrid (Royal Botanical Garden of Madrid). Other two charts were included, showing the sexual botanical method and all his possible classifications done by Carlos Lineo. Both charts had been copied from Casimiro Gómez Ortega's work.

With this work, Julián de Cervantes showed in a systematic way the deep and detailed observation method for the botanical field, giving descriptions, names, shapes, texture, dimensions and other aspects sensed and learned by the senses. This would allow at the expert of the time to locate the plant according to the main characteristics that he could see in the parts of the plant. It was a detailed classification based on visual description, but, it did 


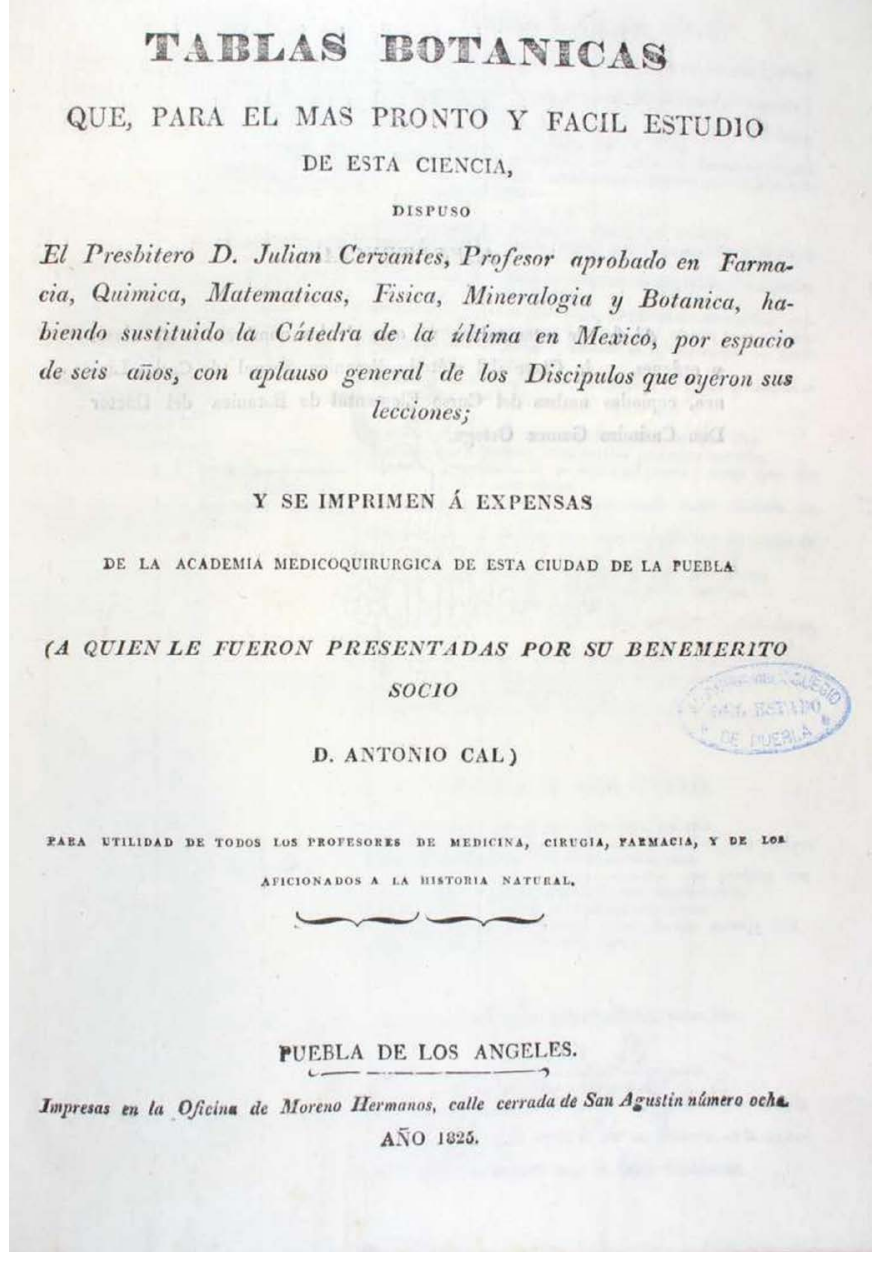

Figure 4. Title page of the book "Tablas Botánicas" [9]. Source: http://www.lafragua.buap.mx/.

not consider the function or the inner composition probably because botanic used to be only a descriptive science in which the objects would be determined by direct observation. This shows an initial stage of the academy works, in which botanic was related to other disciplines, such as medicine.

\subsection{The First Approach for a Mexican Pharmacopeia}

The Academy of Puebla assembled a commission to elaborate a Mexican pharmacopeia which was led by Antonio de La Cal [2]. Once the task was completed, Antonio De La Cal asked to the Academy to give soon approbation and publish it because he feared that a similar work would be published in the capital city before theirs. The first national pharmacopeia was published in 1832 under the name of Ensayo para la Materia Medica Mexicana (Essay for the Mexican Medical Subject) [10].

Some of the assignments of this work were: 1) how to minimize the damages that may result from the lack of knowledge from the humanity's behalf; 2) to reduce the generic and specific names of a wide collection of commercial plants, because they were know by the vulgar name, and sometimes they would be confused with other species; 3 ) to help the medicine teachers by giving them botanical training and knowledge which would allow them to develop themselves better; 4) to provide a first work that the professionals of the subject could be improving up to consolidating a Mexican medical matter.

The thematic content of this book was arranged in 3 main topics such as vegetal kingdom, animal kingdom and mineral kingdom. The vegetal kingdom contains a list of 111 medicinal plants, 26 would be repeated due to their 
vulgar name. In this case only the most common known names would be explained. For each plant, the vulgar name would be given as well as the results from studies performed on them, and also some comments on their potential features in terms of medical resources native from the country.

After the 3 sections, 2 indexes would be included; they only listed the medical plants. The first one respected to the way in which the plants were named, first by their vulgar name and then, in parenthesis and in small caps, the scientific name which was nominated at the time as generic or specific. The second one showed their location in the book by giving first the specific name and then the generic one.

In this essay, a Sucedáneos (comparison between 2 substances and their medical properties, so one could be replaced by another) list would be added. The list included 45 medicinal plants (in which 5 were duplicated), particularly those ones the authors considered the ones to be replaced daily by the people with other completely different from the real ones which are mentioned in foreign medicine subjects, specially when the plants (the real ones and the replacements) would not keep any affinity at all to each other.

At the end of this book an extract of Mariano Mocino's speech was included. The speech was given in 1801 due to the opening of the botanical lessons in Mexico City and a mistake correction section would be added too.

From the deep analysis of this essay, we can notice the work evolution done by Medical and Surgical Academy of Puebla de los Ángeles, as well as the vision and aspirations compared to its first working days, from which we can learn as follows:

1. Already there were established precise medical indications, in multiple cases, product of the own experimentation, these were giving each other depending on the type of patients, clarifying the form of ingestion and raising strategies to offset the possible adverse reactions from the medical treatment.

2. In some cases and when necessary, and according to the treatment phase, the use of the different parts of the plant and the possible combination with other plants would be applied.

3. The indigenous use of the plants was also mentioned in a reference made in the works by Francisco Hernández as well as in the case of the plants originally from different places of the Republic of Mexico used and traded in different places from where the plants were originally. However, experimentation was said to be the method to prove the knowledge of the vulgar use of the plants being the teacher the ones who could take over the assignment and it would be clarified when the effects would not be proved in literary works, and it was clarified when the effects indicated in the literature had not been corroborated in his own laboratory. For this reason the commission performance is considered as one of vital prudence and circumspection [6].

4. The scientific publishing was used; this one was part of the main work to promote the results obtained from the researches detailing the observations and conclusions of some studied cases.

5. They were in the avant-garde in their subjects as they mentioned the different botanical identifiers of the plants, they quoted Francisco Hernández, José Alzate, Casimiro Gómez Ortega, Linneo and other sources of information as well as old and current from the time. They also looked for support on the contemporary observations from other places in the country, and even on the Universal Pharmacopeia which contents would be contrasted with the own results from the laboratory or the medical practice. They corrected mistakes in any international identification, like the Plumier and Lignon case, who had traveled to America reporting that the Maravilla plant was picked up of Jalapa plant but it was not, actually it was a question of two different vegetables.

6. One of the concerns that motivated the proposal of replacing imported plants for locals, besides the high prices, was the low quality and that their condition was not always pure, so it was the Tescalama plant case which grew in Mexico, and was compared with the well-know Ocuje plant from La Havana [10]. However, it is important to make clear that they were reserved for cases when lacking an effective and national Sucedáneo, this was the case of the Yedra Terrestre plant (Glecoma hederacea L.) which national replacements were hazardous to health and its benefits would lack scientific confirmation.

\section{The Academy Closing Down}

After nine working years and by the end of 1833, Medical and Surgical Academy of Puebla de los Ángeles became La Sociedad Médica de Puebla (The Medical Society of Puebla) as result of a new administration promoted by Patricio Furlong current governor of Puebla [2]. This transition occurred after De la Cal had died in July of the same year.

Despite of the constant defense of the academy to keep the unification of surgery and medicine together in the same practice, some authors [4] say that the transformation in to the society happened as a result of the disputes on 
the practical and official separation between the medical and surgical practices, especially about if surgeons could be considered real doctors. The idea of the division between doctors and surgeons could only be proved in an inner way with a sketched administrative hierarchy of the initial organization of this Academy, beyond this, there are not historiographical elements to prove that the inner conflicts really happened. But instead, it seemed as shown in the works by Guerrero [12], that the division of these professions was being promoted by Puebla political power (by the congressmen and the new governmental organization). This might shows an attempt to stop the growth and possible power that the members of the academy were gaining before the society. More over these politics were not coherent and would oppose what was being promoted at the time in a national level, not with the stages already overcome of division between the surgery and the medicine in the above mentioned city, point that was precisely the one that allowed the joint of diverse sectors for the integration and foundation of the Academy for the promotion of the social well-being.

In this way, the historiographical elements that showed the visionary ideology of the academy to fusion the doctor and surgeon professions and practices in one medic science, recognizing the doctors work as legitimate we can emphasize that: 1 ) the promotion of the unification of medicine and surgery which dates since 1825 as shown in the works of Manuel Menéndez, Mariano Escalante y Juan Nepomuceno Raudón; 2) the book Memoria acerca de la utilidad de la unión de la medicina y la cirugía (Memory about the utility of the union of medicine and surgery) were published in 1826 by Pedro Calderón; this author was a doctor and surgeon of Medical and Surgical Academy of Puebla de los Ángeles, and he seem to have performed an important role in the academy writing one of three academy works; 3) the constant counter arguments by Luis Guerrero [12] who from his position as member of the academy, opposed the medicine and surgery division as he stated in his text named Replica contra la división de cirugía y medicina, y la cuestión subalterna de los cirujanos que se pueden considerar como verdaderos doctores (An argument against de division of medicine and surgery and the matter that surgeons as they are, can be considered real doctors), a piece of this work was read in the Medical and Surgical Academy of Puebla de los Ángeles on April 13th of 1833 which Guerrero himself would give a follow-up in the law and governmental matters even beyond the academy working years.

So, while promoting since 1824 the union of the two sciences in one academic body, the members of the academy were also promoting a conception and a different practice for medicine; they stated that surgery and medicine are parts of the real medical practice. With this, they were questioning the political, scientific and religious order which would come from the medieval times in Europe and set in La Nueva España (Spanish Colony) under the Protomedicatos (medical tribunal that would recognize future doctors) control. Then, the quoted Luis Guerrero's argument and his previous expressions, including the academy integration, itself configured a scientific and political modern position different and visionary for the context which appealed to a different way of conceiving and execute the medical practice.

\section{The Historical Burying of the Academy}

After closing down, the works of the academy would be forgotten in history. This was the first scientific institution in the Independent period of Mexico which did the research on the indigenous knowledge of medical plants and the first to launch a Mexican book on botanic and another one with the first approach and the first argument for a national pharmacopeia. But on the academy would weight a substantially influence (feared by Antonio De La Cal) from La Academia Farmacéutica de la Ciudad de México (The Pharmaceutical Academy of Mexico City), which was founded in 1838 and tried to keep the Puebla predecessor anonymous and stating in its Farmacopea Mexicana (Mexican pharmacopeia) published in 1846 that it's only background was the colonial pharmacopeias as well as the foreign ones referred in the Independent times [6]. Nevertheless, this second pharmacopeia included four main points some of them were the Ensayo para la materia médica mexicana published 14 years back in the Medical and Surgical Academy of Puebla de los Ángeles. One of the main points was the replacement of the foreign substances known as exotic for the indigenous ones [6].

Despite the short life of The Pharmaceutical Academy of Mexico City which had despaired once the Farmacopea Mexicana was published [13] and which would be better recognized than the Ensayo para la Materia Médica Mexicana, because the latter book was edited in different versions (1874, 1884, 1896,1904 and 1925). Later on 1930 [7] it would change the name from Farmacopea Mexicana to Farmacopea Nacional (National Pharmacopeia). This latter Pharmacopeia would become the National Health System current and official pharmacopeia. 
Currently the Medical and Surgical Academy of Puebla de los Ángeles is not well known and practically it is not considered to be a topic of the Mexican science history and also because there are a very few texts (which are difficult to find due to their age and location) that mention it. Because of this, the purpose of this work is to recover the history of the Academy of Puebla, so it could be placed in history and teach about the efforts, research and works on the indigenous knowledge on medical plants, and their participation in the fields of botanic, chemistry and medicine.

\section{Conclusions}

Even though the Medical and Surgical Academy of Puebla de los Ángeles is barely known, it can be considered in a legitimate way as the first scientific institution that focused on the study of the indigenous knowledge of the medical plants, due to its existence which was supported by four elements that would recognize it as such: 1) it was authorized and supported by the local, state and federal government; 2) the political structures of the state and local government worked in a coordinated way along with the academy; 3) they recognized it as an essential site to promote the full health benefits; 4) the academy obtained a formal economic help fee which came from the state taxes.

Although the above mentioned Academy of Puebla de los Ángeles can be considered to be the first institutional effort for the scientific research on the indigenous medicinal plants (realized from the botany, the chemistry and the medicine) in the Independent period of Mexico, in his foundation and in his main works a notable foreign influence is observed, particularly of Spain, France and London. For example the idea of having a national pharmacopeia was prompted by a group led by De La Cal who was a foreign scientist and had taken refuge in Mexico and whose ideas linked previous speeches promoted by other foreign works which collected plants in Mexico like the ones done by José Mariano Mociño and Vicente Cervantes [10].

Also the academy was considered to be very advanced for its time because since its foundations it aspired to take control of the medical profession used to be regulated by the Protomedicato referee. Owing to its alliance with the federal, state and local government, the Academy members were able to regulate their professional practices. The academy was one of the first scientific academies to promote and defend a different medicine practice; it had a conception which opposed the previous order in its context and unified the objects of study, the people and the knowledge of medicine in a different way of a whole and equivalent relation between medicine and surgery.

On the other hand, differing with Huerta [2], it is possible to conclude that the Ensayo para la Materia Medica Mexicana was not part of the pharmacopeia for Puebla and it was not a local proposal. On the contrary, the plants presented in the above mentioned work were coming from different places, in different shapes, in different parts and proportions so it would include not only the local ones but also the foreigner ones. This work was an attempt for a national pharmacopeia stating the advantages and disadvantages that some Mexican plants would have in comparison with foreign ones (which were named exotic) and were imported at a high price. For this reason the Academy of Puebla de los Ángeles considered appropriate to replace them by those of indigenous use, proposing even some plants as object of deep scientific study for his potential commercialization. One case was the Hipecuana plant-Mexican one and Brazilian one, but the Mexican one would have higher quality and it was more reliable to do business than the one originally from Brazil (p. 21).

Finally it is important to consider the importance of the returning of the indigenous knowledge on medical plants through botany, which was a main subject of Medical and Surgical Academy of Puebla de los Ángeles, and then this knowledge would be recognized as fundamental for the scientific practice though it was considered as an auxiliary science to the effective medical practice so it was turning out indispensable to possess a meticulous preparation on the subject. This returning is shown from the first efforts to identify the indigenous plants to the systematic and collective efforts of teaching, work field and laboratory to integrate a Mexican pharmacopeia based on the indigenous knowledge on plants.

In the same way and along with Medical and Surgical Academy of Puebla de los Ángeles the foundations for the scientific institutionalization of indigenous knowledge on medicinal plants were set; in it a particular way of relation between the representatives of the indigenous knowledge and the representatives of the scientific knowledge was also institutionalized, and this one was a outlined way of hierarchy relation where the traditional knowledge is legitimized and validates in the space of the scientific knowledge that takes only the useful aspects and places it in the space of the commercialization arguing the common well-being, but that precisely with it 
annuls the character traditional and the character indigenous to the above mentioned knowledge. As it will be seen in the future historical works, this relation between objects and characters would become stronger in the approaches of the epochs and future institutions.

\section{Acknowledgements}

Study realized in the frame of PhD Program on Science, Technology and Society of Cinvestav-IPN (Av. Instituto Politécnico Nacional 2508, Col. San Pedro Zacatenco, Delegación Gustavo A. Madero, Apartado Postal 14-740, 07000 México, D.F., México. Telephone: +52 (55) 57473800, Ext. 6780) and the project Environmental Governance in Latin America and the Caribbean (ENGOV) 2011-2015 (FP7-SSH-2010-3/SSH.2010.4.1-2). Guzmán-Rosas thanks Consejo Nacional de Ciencia y Tecnología (Conacyt).

\section{References}

[1] Merlo, J. (1987) Las ciencias en la obra de Zendejas [The Sciences in Zendejas’ Work]. Elementos, 2, 56-68. http://www.elementos.buap.mx/num12/pdf/56.pdf

[2] Huerta, J. (2001). Salus et solatium: El desarrollo de las ciencias médicas en Puebla durante el siglo XIX [Salus et solatium: The Development of the Medical Sciences in Populates during the 19th Century]. BUAP, México.

[3] De Michelli, S. (2003) De academias y académicos [About Academies and Academicians]. Gaceta Médica de México, 139, 281-285. http://www.medigraphic.com/pdfs/gaceta/gm-2003/gm033l.pdf

[4] Fajardo-Ortiz, G. (2002) Un pasado con mucho presente. El Hospital Real de San Pedro [A Past with a Lot of Present. The Royal Hospital of San Pedro]. Cirugía y Cirujanos, 70, 459-467. http://www.medigraphic.com/pdfs/circir/cc-2002/cc026n.pdf

[5] Izquierdo, J. (1961) Discurso de recepción del Dr. J. Joaquín Izquierdo. Academia Mexicana de Historia correspondiente de la Real de Madrid [Welcome Speech of Dr. J. Joaquín Izquierdo. History Mexican Academy Corresponding to the Royal One of Madrid]. http://www.acadmexhistoria.org.mx/pdfs/discursos/SILLON 8 JOAQUIN IZQUIERDO.pdf

[6] Izquierdo, J. (1949) El primer ensayo de farmacopea mexicana [The First Essay for a Mexican Pharmacopeia]. http://repositorio.fciencias.unam.mx:8080/xmlui/bitstream/handle/11154/142585/10VPrimerEnsayo.pdf?sequence=1

[7] Izquierdo, J. (1953) Les origines et le développement de la pharmacopée mexicaine [The Origins and Development of Mexican Pharmacopeia]. Revue d'histoire de la pharmacie, 41, 20.

http://www.persee.fr/web/revues/home/prescript/article/pharm_0035-2349_1953_num_41_136_10276_t1_0020_0000_3

[8] De Olaguíbel, M. (1889) Memoria para la bibliografía científica de México en el siglo XIX [Memory for the Scientific Bibliography of Mexico in the 19th Century]. Promotion Department’s Typographical Office, México.

[9] Cervantes, J. (1825) Tablas botánicas [Botanical Charts]. Moreno Brothers’ Office, Puebla.

[10] Medical and Surgical Academy of Puebla de los Ángeles (1832) Ensayo para la materia medica mexicana [Essay for the Mexican Medical Subject]. San Pedro Hospital's Office, Puebla.

[11] Moreno, B. (1997) La botánica en Puebla [The Botany in Puebla]. Ciencia y cultura elementos, 4, 45-55. http://www.elementos.buap.mx/num27-28/pdf/45.pdf

[12] Guerrero, L. (1833) Replica contra la división de cirugía y medicina, y la cuestión subalterna sobre los cirujanos como son, pueden considerarse como verdaderos médicos [An Argument against de Division of Medicine and Surgery and the Matter That Surgeons As They Are, Can Be Considered Real Doctors]. Medical and Surgical Academy of Puebla de los Ángeles, Puebla.

[13] Aceves-Pastrana, P. (2013) La profesionalización de una farmacia académica en México (Siglos XIX-XX) [The Professionalization of an Academic Pharmacy in Mexico (Centuries XIX-XX)]. In: Kleiche-Dray, M., Zubieta García, J. and Rodríguez-Sala, M., Coords., La institucionalización de las disciplinas científicas en México, UNAM \& IRD, México, 59-95. 